\title{
Eliot's The Waste Land and Surging Nationalisms
}

\author{
Pouneh Saeedi \\ University of Toronto
}

Follow this and additional works at: https://docs.lib.purdue.edu/clcweb

Part of the Comparative Literature Commons, and the Critical and Cultural Studies Commons

Dedicated to the dissemination of scholarly and professional information, Purdue University Press selects, develops, and distributes quality resources in several key subject areas for which its parent university is famous, including business, technology, health, veterinary medicine, and other selected disciplines in the humanities and sciences.

CLCWeb: Comparative Literature and Culture, the peer-reviewed, full-text, and open-access learned journal in the humanities and social sciences, publishes new scholarship following tenets of the discipline of comparative literature and the field of cultural studies designated as "comparative cultural studies." Publications in the journal are indexed in the Annual Bibliography of English Language and Literature (Chadwyck-Healey), the Arts and Humanities Citation Index (Thomson Reuters ISI), the Humanities Index (Wilson), Humanities International Complete (EBSCO), the International Bibliography of the Modern Language Association of America, and Scopus (Elsevier). The journal is affiliated with the Purdue University Press monograph series of Books in Comparative Cultural Studies. Contact: <clcweb@purdue.edu>

\section{Recommended Citation}

Saeedi, Pouneh. "Eliot's The Waste Land and Surging Nationalisms." CLCWeb: Comparative Literature and Culture 13.4 (2011): <https://doi.org/10.7771/1481-4374.1879>

This text has been double-blind peer reviewed by $2+1$ experts in the field.

The above text, published by Purdue University Press (CPurdue University, has been downloaded 4204 times as of 11/ 07/19.

This document has been made available through Purdue e-Pubs, a service of the Purdue University Libraries. Please contact epubs@purdue.edu for additional information.

This is an Open Access journal. This means that it uses a funding model that does not charge readers or their institutions for access. Readers may freely read, download, copy, distribute, print, search, or link to the full texts of articles. This journal is covered under the CC BY-NC-ND license. 


\title{
PURDUE
}

UNIVERSITY PRESS < http://www.thepress.purdue.edu>

\section{CLCWeb: Comparative Literature and Culture}

ISSN 1481-4374 <http://docs.lib.purdue.edu/clcweb> Purdue University Press (C)Purdue University

CLCWeb: Comparative Literature and Culture, the peer-reviewed, full-text, and open-access learned journal in the humanities and social sciences, publishes new scholarship following tenets of the discipline of comparative literature and the field of cultural studies designated as "comparative cultural studies." In addition to the publication of articles, the journal publishes review articles of scholarly books and publishes research material in its Library Series. Publications in the journal are indexed in the Annual Bibliography of English Language and Literature (Chadwyck-Healey), the Arts and Humanities Citation Index (Thomson Reuters ISI), the Humanities Index (Wilson), Humanities International Complete (EBSCO), the International Bibliography of the Modern Language Association of America, and Scopus (Elsevier). The journal is affiliated with the Purdue University Press monograph series of Books in Comparative Cultural Studies. Contact: <clcweb@purdue.edu>

\section{Volume 13 Issue 4 (December 2011) Article 14 Pouneh Saeedi, \\ "Eliot's The Waste Land and Surging Nationalisms" \\ <http://docs.lib.purdue.edu/clcweb/vol13/iss4/14>}

Contents of CLCWeb: Comparative Literature and Culture 13.4 (2011)

<http://docs.lib.purdue.edu/clcweb/vol13/iss4/>

\begin{abstract}
In her article "Eliot's The Waste Land and Surging Nationalisms" Pouneh Saeedi analyzes T.S. Eliot's poem in the context of the impact of World War I and the emergence of nationalisms. In the midst of the ruins of both his personal life and Europe as he understand its civilization, Eliot expresses the loss of a universal understanding delineated in the fragmentation of language and a disassociation of sensibility. In The Waste Land, the West and the East, represented in their respective canonical texts, commingle and cohere to present an image of oneness that goes beyond oppositional binaries and leads the egotistical self to look beyond antagonistic dichotomies and ultimately embrace a peace beyond national and linguistic boundaries.
\end{abstract}




\section{Pouneh SAEEDI}

\section{Eliot's The Waste Land and Surging Nationalisms}

Prior to taking a look at particular sections of T.S. Eliot's The Waste Land which shed light on the impact of the cataclysmic events associated with World War I, I deem it necessary to explicate some other factors which could have made Eliot susceptible to the aftermath of the Great War. For one thing, one ought not to exclude the influence of the "double vision" which Eliot had come to develop as a result of his sense of belonging to the two disparate Anglophone countries - the U.S. and England -from any in-depth analysis of his works. Worthy of note is Eliot's tendencies towards an allencompassing absolute as is indicated already in his dissertation, published in 1964 as Knowledge and Experience in the Philosophy of F.H. Bradley. Bradley (1846-1924) was a proponent of an absolute that encompassed both good and evil. Although Bradley's concept of "the finite centre," which suggests that each person's experience falls within his/her circle, "a circle closed on the outside and opaque to the others which surround it" (346), might smack of an extremely insular form of hermetism, the fact that all our circles, ultimately, constitute part of an absolute, hints otherwise. Building upon Bradley's concept of the absolute, Eliot writes the following: "the life of a soul does not consist in the contemplation of one consistent world but in the painful task of unifying (to a greater or lesser extent) jarring and incompatible ones, and passing, when possible, from two or more discordant viewpoints to a higher which shall somehow include and transmute them"(Knowledge 147-48). Also in his dissertation on Bradley, Eliot groups explicitly good and evil within the same matrix in positing that "both God and Mammon are interpretations of the world and have to be reinterpreted" (Knowledge 164). Additionally, Eliot's coinage of the phrase "dissociation of sensibility" in reference to the irreparable schism between experience of feeling and intellectual thought, hints at an approach similarly holistic in nature. In his essay "The Metaphysical Poets," Eliot speaks against a compartmentalization of poetic experience: "We may express the difference by the following theory: The poets of the seventeenth century, the successors of the dramatists of the sixteenth, possessed a mechanism of sensibility which could devour any kind of experience. They are simple, artificial, difficult, or fantastic, as their predecessors were; no less nor more than Dante, Guido Cavalcanti, Guinicelli, or Cino. In the seventeenth century a dissociation of sensibility set in, from which we have never recovered" (Selected Essays 287-88).

The call for coincidentia oppositorum that foregrounds Eliot's argument surpasses the scope of his theoretical oeuvre and goes on to extensive presence in his poems. A perusal of his The Love Song of J. Alfred Prufrock suffices to shed light on his fondness for coalescing disparate images into integral poetic units. As the narrative voice of the poem wanders through festive and funereal landscapes evoking images of both life and death, those of us affected by the malaise of "dissociation of sensibility," begin to wonder what the poem is all about. "Murdering" and "creating" are mentioned in the same vein, so are images of life and death, as is the case with Eliot's evocation of Dante's catabasis in the epigraph where Dante meets Guido da Montefeltro, a military strategist, who is condemned by Dante the poet, to the Eighth Circle of Hell for giving false counsel. Death and life commingle in the figure of Dante in the epitaph of the poem and Lazarus. In the former, in view of the fact that his sojourn to the Underworld take place while he is still alive in the flesh; in the latter, for the reverse reason, for Lazarus comes back to life only upon being raised from the dead by Jesus. Given the time-frame of the composition of The Love Song of J. Alfred Prufrock, there is little wonder as to why Eliot's poem should be infused with such intense images. The imagery becomes even more cataclysmic in his later poems including The Waste Land in which, similar to The Love Song, he uses a wide-ranging spectrum of literary allusions.

An all-embracing view of the world, concretized in the stillness and serenity of the "rose-garden" delineated in Eliot's later series of poems entitled Four Quartets could have been strengthened as a consequence of his exposure to Eastern teachings. For one thing, it is known that when a student at Harvard by C.R. Laman in Indian philosophy, he read The Twenty-Eight Upanishads, a text that impacted his thinking in many ways. Although Eliot acknowledged that "my only hope of really penetrating to the heart of the mystery would lie in forgetting how to think and feel as an American or 
a European: which, for practical as well as sentimental reasons, I did not wish to do" (After Strange Gods 43), there is no denying that Buddhism had heightened his tolerance towards disparate aspects of the world. Mental boundaries and bifurcations are lifted one after another, or so one can conclude, in view of an endorsement of a reconciliation of opposites observed in most of his works, in particular, The Waste Land whose first low notes concretized in an April that fails to bear the tidings of rejuvenating spring reach full circle upon hitting the high notes of exaltation in the "shantih, shantih, shantih" that finalize the poem. In addition, the echoic repetition of the Sanskrit word for "peace" bids the reader to embrace the impersonal approach, also inherent in Buddhist guidelines, that the poet was so much in favour of. After all, Eliot espoused a poetic process which did not engage in the expression of personality, but, rather, encouraged an escape from it (After Strange Gods 43). An impersonal approach was to be a prelude to a plenitude expressed in, what Eliot in his reading of Dante's works calls the "high dream," which far from being the wish fulfilment of the mundane ego in the "low dream," was expressive of a vision "a practice now relegated to the aberrant and uneducated" (Selected Essays 243).

A look at Canto 33 of Dante's Paradiso, where the "Highest Heaven" or the "Empyrean" is depicted, could help shed further light on Eliot's interpretation of the "high dream." In this last canto of the Commedia we encounter images that can be best described as "ineffable" harking back to the first canto of the Paradiso where the image of Glaucus's sudden transformation from ordinary fisherman to a sea-god is described as, "passing beyond the human cannot be/worded" ("trasumanar significar per verba/non si poria" [Paragraph 1 70-71]). The image of the "white rose" in the last canto of the Paradiso is best described as "ineffable," as it points to a referent beyond our mundane existence "where what, in the universe, seems separate, scattered," becomes "ingathered and bound by love into one single volume" (Paragraph 33 85-87). As observed by Marguerite Mills Chiarenza, "when the universe is transcended, what was separate becomes unified just as all the pages when bound become the book" (75). The antecedent to a book of such totality can be found in the Apocalypse where there is "a book written within and without, sealed with seven seals" (5:1 "librum scriptum intus et foris signatum sigillis septem"), which when folded up "every mountain, and the islands were moved out of their places" (6: 14 "omnis mons et insulae de locis suis motae sunt") (Biblical passages are based on the Douay Rheims Bible). However, it takes a certain level of perception to observe the book in its totality and comprehend its hidden meaning. To acquire a vision that would enable the experiencing of a "high dream," one would need to attain such a high level of ex-stasis conducive to the visio intellectualis (St. Augustine), as being greater than the two other kinds of visions that precede it, the visio corporalis and the visio spiritualis. It is the visio intellectualis that leads to St. Paul's otherworldly experiencing of the "third heaven" (tertium caelum), according to the Bishop of Hippo in a state of ex-stasis, which transcends the corporeal and spiritual realms and is akin to what we have come to associate with the "third eye" (see De Genesi ad Litteram, Book 12).

Both Dante and St. Augustine are conspicuously present in the Waste Land and excerpts of their works are represented as embodiments of the Western literary and philosophical canon in juxtaposition with Eastern canonical texts such as The Upanishads. However, prior to reaching the sub specie aeternitatis view of the "third eye" palpable in these works, Eliot exposes his readers to the blurred vision of the "monstrous double." Not only does Eliot evoke the concept of the double by quoting Baudelaire in line 72 of The Waste Land in addressing the reader as "You! Hypocrite lecteur! - mon semblable - mon frère!," but also alludes to another poem from Baudelaire's Les Fleurs du Mal, namely, "Les Sept Veillards" which is dominated by an air of frisson fraternel. The "unreal" in line 376 of The Waste Land harks back to the "monstrous double" which pervades Baudelaire's cité fourmillante in "Les Sept Viellards" ("Seven Old Men") evoking a "swarming city" (176). The deux quais appearing in Baudelaire's poem serve as a prelude to the dédoublement that transpires across Baudelaire's poem as the fiery-eyed old man, both a concretization of the growing gloom that envelopes his "unreal" city and a Doppelgänger to Charon, whose eyes, as described by Dante, are similarly "ringed about with wheels of flame" (see Inferno 3 99), keeps on multiplying. Eliot's "Unreal," which alludes to the fourmillante cité, functions on numerous levels, for it is not only evocative of Baudelaire's city where a doubling of drabness, male impotence, and old age take place, but also draws a parallel between the ravages of war left in the wake of World War I. In addition, monstrosity and the double are so inextricably linked that one could argue that "the double and the monster are 
one and the same being" (Girard 160). As noted by René Girard, in the Greek tragedy of The Bacchae it is only natural for the king of Thebes, Pentheus, to adopt a double-vision of Dionysus, whose worship he has banned within his kingdom, in a monstrous encounter between the two: "I seem to see two suns, two Thebes, with two times seven gates. And you, you are a bull walking before me, with two horns sprouting from your head" (162). Pentheus's double-vision is attributed to the concept of the "monstrous double" as he and his adversary, Dionysus, have become equally monstrous, although "the double appears initially in a form completely exterior to the subject, as a double vision of inanimate objects, an attack of dizziness" (162).

Once we explore Eliot's annotations, we become aware that he is referring to a series of essays by Herman Hesse in his 1920 "A Glimpse of Chaos" ("Blick ins Chaos"). Hesse, writing his series of essays entitled in the wake of World War I, was well aware of the doubling monstrosity running through Dostoevsky's Brothers Karamazov and highlights how Dostoevsky has included a half-veiled fifth double in the figure of Fyodor Pavlovich's illegitimate son, Smerdyakov. The doubling that takes place throughout Dostoevsky's novel takes on monstrous overtones; particularly, after more than one Karamazov becomes implicated in the murder of the father figure Pavlovich: while the crime has been committed by the half-brother, Smerdyakov, the vehicle behind the crime is believed to have been Ivan. Additionally, Ivan's conversation with the devil, who turns out to be his own Doppelgänger, further brings to the fore, the favoring of creative chaos over taxonimic order in the "Asiatic" mind of the Karamazovs. By "Asiatic," Hesse is referring to those who are against any particular established ethical or moral system, favoring a new, dangerous and gruesome form of sanctity that understands and validates everything as is incorporated in the figures of the Karamazov brothers (Hesse 321-22). The intoxicated figure of Dmitri Karamazov whom Eliot alludes to in his Waste Land is the Asiatic par excellence in view of his connection to Dionysus, the god of wine whose doubling in the eyes of Pentheus is in view of his being god and the devil, the primal "demiurge," a figure beyond the realm of opposites, who is simultaneously nothing and everything (Hesse 324). Similar to Eliot, Hesse endorses a Weltanschauung that goes beyond the "double vision" to incorporate the realm where opposites can be reconciled. Hesse's reading of Dostoevsky's The Idiot (1868) and its epileptic protagonist, Prince Myshkin, comes close to Eliot's "high dream," Dante's "Empyrean," and St Augustine's visio intellectualis. Like Eliot, Hesse sees only the "aberrant," in this case, the epileptical, capable of a mental capacity that can encompass the most diverse of worldviews. Epilepsy, a neurological disorder, could be largely responsible for not only Myshkin, but also Dostoevsky's own capacity for "magical thinking." The magical element associated with Myshkin, far from being acquired through books or through study, is experienced effortlessly by "aberrant" individuals. "Magical thinking," according to Hesse, is an ability to affirm everything, a plane of existence where not only remote thoughts are true, but so are the opposite of all those thoughts. The reason as to why characters possessing such an ability are feared is that whoever has felt the realm of the mind and nature as well as good and evil as interchangeable, as is the case with these characters, is the enemy of established order (see Hesse 312). The blurred vision of the "monstrous double" and the inclusive perspective of those afflicted with a sense for magisches Denken is concretized in Eliot's allusive language and his usage of a multiplicity of tongues.

It is my contention that the heteroglossia of The Waste Land along with its fragmentary structure is a reaction to the emerging nationalisms that were engulfing Europe at the turn of the previous century and beyond. As argued by Benedict Anderson, the idea of nationhood came to the fore owing to the fact that: "three fundamental cultural conceptions, all of great antiquity, lost their axiomatic grip on men's minds. The first of these was the idea of that a particular script-language offered privileged access to ontological truth ... Second was the belief that society was naturally organized around and under high centres - monarchs were persons apart from human beings who ruled by some form of cosmological (divine) dispensation ... Third was a conception of temporality in which cosmology and history were indistinguishable, the origins of the world and of men essentially identical" (36). As the parameters of education started to change in the late nineteenth century and the knowledge of Latin and Greek became less important, national languages gained in importance: The Waste Land starts off on funereal note on Latin to give way to other tongues. Privileged Latin might have set the tone for The Waste Land, but as it gives way to a heteroglossia of social class and vernacular languages prevailing over the "Old Continent," we observe how the poem concretizes the 
breakdown it wishes to convey. At the heart of the breakdown that came to overwhelm pre- and postWorld War I Europe is the dominance of nationalism amongst masses who had previously seen themselves as one. The divisive concept of nationhood was a primary factor in igniting warfare between European states including France and Germany as was especially evident in the territory of Alsace-Lorraine, which, despite having been ceded to Germany in the wake of the Franco-Prussian war towards the end of the nineteenth century, along with the dominance of German dialects over French, was regarded as French by most of its inhabitants. Eliot stresses the complexity of nationalism as one of the many descanting voices throughout The Waste Land: "I am not Russian at all; I come from Lithuania, I am a real German" ("Bin gar keine Russin, stamm' aus Litauen, echt deutsch") (line 12). This voice is not only problematic on grounds of its origin, believed by Eliot's widow to have been that of Countess Marie Larisch, who was born in Augsburg, hence, did not come from Lithuania, but also with regard to the history of Lithuania where the Lithuanian language had been denigrated and replaced by Polish and was only revived as the Lithaunian elite, with the rise of nationalist sentiments, sought to learn it from its peasants and low-class citizens. The presumed voice of Larisch goes on to reaffirm her "pure" German identity (as is indicated with the term echt) at a time when a sense of nationalism had galvanized people and the concept of purity of race was about to fuel fanatic sentiments.

Anderson's second hypothesis for the rise of nationalism also figures in The Waste Land, although not as prominently as the first. The ailing figure of the Fisher King in the background, whose impotence can only be cured in the event that a questing knight, is able to grasp the significance of the symbolism of the cup and the lance and associate them with their respective reproductive organs dominates parts of the poem. One could argue that Eliot has dissected the myth and inserted its key components in his poem: "Eliot is concerned less with the familiar pattern of the quest romances than with the sexual rituals and vegetation myths that underlie them. In fact, Eliot actually breaks down the traditional story by fragmenting it into its primal components: in The Waste Land the figure of the Fisher King subsumes such disparate figures as Osiris, Christ, the Phoenician Sailor, and the hanged man of the Tarot deck" (Ziolkowski 270). The presence of the myth of the Fisher King in The Waste Land, regardless of its scope of influence, is testimony enough to the crumbling of the undivided centrality accorded to kings in previous centuries and along with it the collapse of monolithic figureheads whose influence used to suffice to keep peoples of diverse languages and races united. The scourge afflicting "The Waste Land," literally, comes in the wake of the impotence of the Fisher King, yet, figuratively, it represents the fragmentation that has afflicted the "Old Continent."

Anderson's third hypothesis on the emergence of nationalism, namely the disruption of the cosmohistoriographical continuum that used to dominate universal narratives is also à propos to the composition of The Waste Land which brings to the fore how the crumbling of empires has led to the fragmentation of their cosmological historiae. Once the inextricability of cosmologies and histories has been invalidated, poets and writers engage in an archaeology of knowledge on the basis of the classical corpus of literature and folklore that has been passed down to them. One great reservoir of knowledge for poets who had experienced the traumas of World War I to tap into is mythology. In fact, in an analysis of James Joyce's Ulysses, Eliot writes that "in using the myth, in manipulating a continuous parallel between contemporaneity and antiquity, Mr. Joyce is pursuing a method which others must pursue after him ... It is simply a way of controlling, of ordering, of giving shape and a significance to the immense panorama of futility and anarchy which is contemporary history ... Instead of narrative method, we may now use the mythical method" ("'Ulysses'" 177-78). No wonder why rather than resort to historiography, Eliot has the myth of the Fisher King dominate The Waste Land. Similar to Joyce, he weaves this myth into a multi-layered maze of intertextuality, the unraveling of which, despite the annotations provided by the poet, seem like an impossible task. However, within the context of Anderson's hypothesis on the interrelationship between the disjointedness of history and cosmology and the emergence of nationalist sentiments, it is interesting to see this rupture delineated not only in the replacement of history by mythology, but also by the poet's use of an apocalyptic tone. The apocalypse portrayed by Eliot comes in the wake of the fragmentation of tongues, the rupture of universal unity, and the disunity felt by human beings towards their surroundings. 
The thunderous note that fills the air in the final part of Eliot's The Waste Land, as its subtitle of "What the Thunder Said" indicates, resonates with a foreboding of the catastrophes ahead. Against the backdrop of the Upanishad and the repetition of "Da," Eliot meshes a web of allusions, each of which assumes apocalyptic overtones upon deep investigation:

I sat upon the shore

Fishing, with the arid plain behind me

Shall I at least set my lands in order?

London Bridge is falling down falling down falling down

Poi s'ascose nel foco che gli affina

Quando fiam uti chelidon - O swallow swallow

Le Prince d'Aquitaine á la tour abolie

These fragments I have shored against my ruins

When Ile fit you. Hieronymo's mad againe.

Datta. Dayadhvam. Damyata.

Shantih shantih shantih (lines 423-33)

The image of the crumbling London Bridge (line 426) takes us back to Dante's Inferno and the doubting denizen of the Vestibule. The Dantesque mood prevails in the following line as Eliot alludes to the character of Dante meeting with twelfth-century troubador Arnaut Daniel, the only character to address Dante in his own native Provençal. As Eliot brings The Waste Land to a close, we come full circle in that the epithet of il miglior fabbro ("the better craftsman") used in reference to his contemporary, Ezra Pound and it is evoked in its having been used by Dante to describe the poetic skills of Arnaut Daniel. Eliot refrains from quoting Dante's miglior fabbro in the latter's native Provençal and refers to the final verse of Canto XXVI of the Purgatorio only after he has finished his speech. Yet, even the concatenation of Latin, Italian, French, and Sanskrit, although building up to a reverberation of "peace," is embedded in an apocalyptic intertextuality surrounding the image of a darkened sun amid an amalgamation of a breakdown of tongues.

The apocalyptic image of the blackened sun is an integral part of the last lines of The Waste Land, yet, it is only by the untangling of intertexts that it takes on added meaning. Not only is Canto XXVI of Dante's Purgatorio dominated by a sun whose rays are altering (lines 4-7), but also there is mention of le Soleil Noir in El Desdichado of Gérard de Nerval shortly after the following line, which Eliot has incorporated into his text: "the prince of Aquitaine to the ruined tower" ("Le Prince d'Aquitaine à la tour abolie). The layers of intertextuality thicken once we take into consideration the impact of Heinrich Heine's poem "Der Schiffbrüchige" on Nerval who translated it into French 1848, as well as Walter Scott's historical novel Ivanhoe, whose plot coheres around the figure of a disinherited knight nicknamed "Desdichado" (for further details, see, for example: Ralph Häfner, "Images of the Black Sun"]. Both the "Desdichado" of Ivanhoe and "Der Schiffbrüchige" of Heine's poem have been disowned, the former by his father, the latter by a lovely lady whose eye is likened to "a black sun" ("eine schwarze Sonne"). Latent images of the apocalyptic "black sun" in The Waste Land intermingle with an eschatological water imagery as the Fisher King is grounded in a web of intertextuality which brings to the fore the river of Acheron both in the falling London Bridge (line 426) and the narrative voice of Nerval's El Desdichado who claims to have traversed it twice ("je deux fois vainquer traversé l'Acheron").

Amid the water imagery - which is juxtaposed with the dryness and barrenness of the scene the sound of thunder, "da," comes to be interpreted in three different ways as gods, men, and demons, respectively, and translate it into "to give," '"to sympathize," and "to control." This multiplicity of interpretations, along with a plethora of languages deployed by Eliot towards the end of his text, highlights the inadequacy of language, especially against a political backdrop where vernacular tongues were fomenting divisive nationalist sentiments. The image of Nerval's tour abolie, if it were to be taken as a tarot card symbolizing the Tower of Babel, along with a reference to the metamorphosis of Philomela (mythical daughter of the Athenian king) into a swallow after she is raped and has her tongue cut off by king Tereus of Thrace, further highlights the breakdown of understanding amongst people as a result of the collapse of linguistic unity. In addition, within the same context of loss of the Ur-tongue of the human race, Eliot alludes to the sixteenth-century Elizabethan tragedy, The Spanish Tragedy in which a Spanish knight Hieronimo bites off his own tongue after having avenged his son's murderers. Aside from stressing the ontological inadequacy of 
languages from a historical perspective, Eliot could have been referring to the trail of destruction that was left in the wake of World War I as a result of an overemphasis on the significance of vernacular tongues following the emergence of nationalism, which is, inherently, predicated upon the cementing of a sense of unity amongst the "us" at the cost of excluding the "them."

A call for breaking the shell of egocentricism and establishing unity with the Other is heard towards the end of The Waste Land as Eliot evokes claustrophobic images of enclosed and ruined towers to be interpreted both as symbols of the impenetrable circle of our personal experiences, an image reinforced by the poet's involvement with Bradley's solipsism and Nerval's Desdichado, as well as Dante's depiction of the thirteenth-century politician Ugolino in the lowest circle of the Inferno. As history has it, Ugolino and his two sons and two grandsons were left to starve to death in the Tower of Muda in Pisa once the keys to the tower are thrown into a river hindering any reversal of fate: "Da / Dayadhvam: I have heard the key / Turn in the door once and turn once only / We think of the key, each in his prison / Thinking of the key, each confirms a prison / Only at nightfall, aethereal rumours / Revive for a moment a broken Coriolanus" (lines 410-16). Both Ugolino and Coriolanus were powerhungry politicians whose sole interest was the preservation of their own hold on power, be it at the cost of their own people. As Eliot brings The Waste Land to a close, a call for the shattering of the ego and the embracing of the Other is echoed throughout the poem. One of the reasons as to why images of fire and burning are interspersed across the poem is in line with a call for self-purification and ultimately nirvana. Eliot alludes to Dido who ends up committing suicide in an act of self-conflagration in Virgil's Aeneid only to move on to parts of St. Augustine's Confessions in which the Bishop of Hippo had come to Carthage, "where a cauldron of unholy loves sang all about mine ears" ("circumstrepebat me undique sartago flagitosorum amorum") (Book $3 \mathrm{I}$ ), as well as a section, where, upon being ensnared by outward beauties he realizes that "O Lord Thou pluckest (me) out" ("sed tu evelles, domine, evelles tu" (Book 10 XXXIV). In the same vein, Eliot invokes Buddha's Fire Sermon where Buddha, similar to St. Augustine, refers to the temptations of the eye/I and instructs his priests that all things "are on fire ... The eye ... is on fire; forms are on fire; eye-consciousness is on fire; impressions received by the eye are on fire; and whatever sensation, pleasant, unpleasant, or indifferent, originates in dependence on impressions received by the eye, that is also on fire. And with what are these on fire? With the fire of passion, say I, with the fire of hatred, with the fire of infatuation" (The Annotated 99-100). The theme of fire continues up to the final stanza of the poem where Eliot alludes to the refining fire in which Daniel Arnaut hid. Ultimately, the echoic evocation of "peace beyond understanding" in the final line of The Waste Land can only be attained if the geographical and linguistic boundaries which incited World War I are put aside.

In conclusion, The Waste Land is a dismantling of divisive factors concretized in artistic form. The doubling, although initially monstrous, turns into a tripling in the threatening tripartite readings of "da" and ultimately gives way to "peace" in the triple invocation of "shantih." However, despite the "Asiatic" echoes of "shantih" in which we sense a removal of divisions and a reverberation of Hesse's "magical thinking," the threat of monstrosity looms large in the irreconcilable water-and-fire imagery, for although, in the system of the four elements, fire and air existed in harmonious relation to each other, just as did earth and water, "fire and water, however, being binary opposites, were forever divided: they were never to unite except in catastrophe" (Williams 178). Eliot remained skeptical of the times after World War I and he felt the seeds of another world-shattering war lingering in the air and as a poet imbued with a serendipity he felt another apocalypse coming.

\section{Works Cited}

Anderson, Benedict. Imagined Communities: Reflections on the Origin and Spread of Nationalism. London: Verso, 1991.

Augustine. De genesi ad litteram libri duodecim. Ed. Iosephus Zycha. Prague: F. Tempsky, 1894.

Baudelaire, Charles. The Flowers of Evil. Trans. James Mcgowan. Oxford: Oxford UP, 1993.

Bradley, F.H. Appearance and Reality: A Metaphysical Essay. Oxford: Clarendon P, 1930.

Dante, Alighieri. The Divine Comedy. Trans. Allen Mandelbaum. New York: Bantam Dell, 1980. 3 Vols.

Eliot, T.S. After Strange Gods. London: Faber \& Faber, 1934.

Eliot, T.S. Knowledge and Experience in the Philosophy of F.H. Bradley. London: Faber \& Faber, 1964.

Eliot, T.S. Selected Essays. London: Faber \& Faber, 1951.

Eliot, T.S. The Annotated Waste Land with Eliot's Contemporary Prose. Ed. Lawrence Rainey. Devon: Scala, 2005. Eliot, T.S. The Waste Land and Other Poems. Ed. Frank Kermode. London: Penguin, 1998. 
Eliot, T.S. "'Ulysses,' Order, and Myth." Selected Prose of T.S. Eliot. By T.S. Eliot. New York: Harcourt Brace Jovanovich, 1975. 175-78.

Girard, René. Violence and the Sacred. Trans. Patrick Gregory. Baltimore: The Johns Hopkins UP, 1977.

Häfner, Ralph, "Images of the Black Sun: Notes on the Relationship between Heinrich Heine and Gérard de Nerval." Revue de littérature comparée 3 (2006): 285-98.

Hesse, Hermann. Eine Literaturgeschichte in Rezensionen und Aufsätzen. Frankfurt: Suhrkamp, 1970.

Mills Chiarenza, Marguerite. "The Imageless Vision and Dante's Paradiso." Dante Studies 90 (1972): 77-91.

Williams, David E. Deformed Discourse: The Function of the Monster in Medieval Thought and Literature. Montréal: McGill-Queen's UP, 1996.

Ziolkowski, Theodore. "Wagner's Parsifal between Mystery and Mummery; or, Race, Class, and Gender in Bayreuth." The Return of Thematic Criticism. Ed. Werner Sollors. Cambridge: Harvard UP, 1993. 261-86.

Author's profile: Pouneh Saeedi teaches gender studies and cultural studies at the University of Toronto. Her interests in research include culture and globalization in a comparative context, fashion studies, and image studies. Saeedi's recent publications include "Clothing and Colonialism in Conrad's Heart of Darkness," Transatlantic Dress (Ed. Katherine Josling and Daneen Wardrop, 2012) and "Images of Liminality in Book VI of The Aeneid," CLCWeb: Comparative Literature and Culture (2009). Saeedi is also a journalist and published her work in Iranian and U.S. and Canadian newspapers. She has translated Negin-e Pars: Takht-e Jamshid to English as Pearl of Persia: Persepolis (2004). E-mail: <pouneh.saeedi@utoronto.ca> 